\title{
New Data to the Knowledge on the Corticolous Mite Fauna in Hungary (Acari: Prostigmata, Astigmata, Oribatida)
}

\author{
G. RIPKA ${ }^{1}$, A. FAIN ${ }^{2}$ and H. R. BOLLAND ${ }^{3}$ \\ ${ }^{1}$ Plant Health and Soil Conservation Station of Budapest, H-1519 Budapest, Hungary \\ ${ }^{2}$ Institut royal des Sciences naturelles de Belgique, B-1000 Bruxelles, Belgium \\ ${ }^{3}$ Institute of Systematics and Population Biology, University of Amsterdam, \\ 1098 SM Amsterdam, The Netherlands
}

\begin{abstract}
Authors give a report on the results of the regular collections made between 1990 and 1998 on ornamental trees and shrubs, on streets, in parks, in green spaces of housing estates, in private gardens and in arboreta. A total of 19 corticolous mite species were found belonging to 14 families. Michaelopus corticalis (Michael, 1885), Hericia hericia Robin, 1868, Eupalopsis maseriensis (Canestrini et Fanzago, 1876), Mediolata vandergeesti (Gomaa et Bolland, 1982), Cunaxoides kielczewskii Michocka, 1982, and Neophyllobius spec. nov. are reported for the first time for the Hungarian fauna. Hemisarcoptes budensis Fain et Ripka, 1998, M. corticalis and Cheletogenes ornatus (Canestrini et Fanzago, 1876) were the most frequent species in the acarofauna associated with scale insects.
\end{abstract}

Key words: Corticolous Mites, Acari, Prostigmata, Astigmata, Oribatida

Among arboreal mites corticolous mites are less known contrary to foliagedwelling mites. In the last three decades, Lebrun (1976), André (1986, 1987), Momen (1987, 1988), Momen and Lundqvist (1996), Suski (1972), Doberski (1986), Bolland (1983, 1986, 1991), Smiley (1992), Kehl and Weigmann (1992), Weigmann and Jung (1992) studied the mites on bark of trees and shrubs. Their results proved the considerable richness of corticolous acarofauna.

A part of cortex-dwelling mites is algae and lichens feeder. An other group is fungivorous and saprophagous. The third group is predaceous upon the smallest arthropods. In Belgium, André (1986) reported 22 species of Tydeidae and 6 species of Stigmaeidae from bark of different tree species. In Bulgaria, Nachev and Trenchev (1987), while in Italy, Vacante (1989) as well as Vacante and Gerson (1987) reported the mites found associated with coccids from fruit trees. Nachev and Trenchev (1987) observed Thyreophagus entomophagus (Laboulbene), Cheletogenes ornatus (Canestrini et Fanzago), Cheyletia flabellifera (Michael), Hemisarcoptes malus (Shimer), Amblyseius cucumeris (Oudemans) and Bdella iconica Berlese under the shields of Sphaerolecanium prunastri (Fonscolombe), Parlatoria oleae (Colvée), Quadraspidiotus marani Zahradnik and Quadraspidiotus pyri (Lichtenstein). Th. entomophagus was the most frequent species. Vacante (1989) reported H. malus from Lepidosaphes beckii (Newman), Aonidiella aurantii (Maskell), Parlatoria pergandii Comstock and Aspidiotus nerii Bouché. Several members of Stigmaeidae, Eupalopsellidae, Cunaxidae and Camerobiidae are predators of armored scale insects and can be found on the bark of trees (Cooreman, 
1958, Meyer and Ueckermann, 1984, Bolland, 1986, Vacante and Gerson, 1987). Smiley and Knutson (1983), also Gerson $(1973,1985)$ summarized the knowledge on the role and biology of predatory mites of coccids. Fain et al. (1995) as well as Fain and Ripka (1998) reported new species of the genus Hemisarcoptes that predaceous upon diaspidids.

The present knowledge of corticolous mites in Hungary remains scanty. Balogh and Mahunka (1980) reported oribatids, Komlovszky $(1980,1984)$ recorded cunaxid and cheyletid species. Lucza et al. (1996) found 4 cheyletid species on tree bark infested with armored scale insects. Ripka et al. (1997) collected the following 6 tarsonemid species: Tarsonemus nodosus Schaarschmidt, 1959, Tarsonemus lobosus Suski, 1965, Tarsonemus karli Sharonov et Mitrofanov, 1986, Tarsonemus waitei Banks, 1912, Dendroptus willmanni (Schaarschmidt, 1959) and an other Dendroptus sp. together with coccids. Aceria heteronyx (Nalepa, 1891) causes small stem galls on twigs and branches of Acer platanoides. An other eriophyoid mite, Acalitus phloeocoptes (Nalepa, 1890) causes stem galls on Prunus domestica and Prunus spinosa (Ripka and de Lillo, 1997). Ripka and Kaźmierski (1998a) recorded the following 8 tydeid species in association with scale insects: Lorryia reticulata (Oudemans,1928), Lorryia obliqua (Kuznetzov, 1973), Lorryia cf. woolleyi, Triophtydeus immanis Kuznetzov, 1973, Triophtydeus triophthalmus (Oudemans, 1929), Tydeus caudatus (Duges, 1834), Tydeus californicus (Banks, 1904) and Homeopronematus staerki (Schruft, 1972). Out of them T. immanis was the most frequent mite. The following two tydeids: Lorryia reticulata and L. obliqua were found solely on bark. Ripka and Kaźmierski (1998b) found Mediolata mariaefrancae André, 1977 on the bark of tree infested with scale insects.

\section{Materials and Methods}

Between 1990 and 1998, a mite survey was made on ornamental trees and shrubs of streets, squares, parks, botanical gardens, private gardens, and green areas of housing estates in all districts of Budapest (in some other localities in Hungary and Croatia, also herbaceous plants were occasionally examined). Plant samples from 301 woody plant species (minimum 5 shoots, branches or bark/plant or 25 leaves/plant) were taken in plastic bags from January to late November. During plant examination with binocular microscope (upper and lower surfaces of the leaves, petioles, buds, bark, flowers, galls, etc.), all the mites found on the plant samples were put into AGA solution or directly into lactic acid. After the clearing of mites in the lactic acid, they were placed into Keifer's medium 2 following the Keifer's mounting method for eriophyoid mites (Keifer, 1952). The cleaned and dyed mites were then placed into Keifer's medium 3. The Hoyer's medium with sorbitol (Keifer, 1975), and Heinze's polyvinyl alcohol (PVA) medium (Schmutterer, 1959) were used alternatively for mounting the specimens. The slide preparations were dried in thermostat at $32{ }^{\circ} \mathrm{C}$ and then sealed with nail varnish. Specimens were examined with a phase contrast microscope. For mite determination the keys of Fain (1982), Bolland (1991), Smiley (1992) as well as several original species descriptions and other available reports were used. 


\section{Results}

Corticolous mites were collected on 48 woody plant species out of 301 studied belonging to 19 families. These mites were found in 90 plant samples. A total of 19 mite species were identified belonging to 14 families (see Table 1 for the exact host/locality data). The following species were new for the Hungarian fauna: Cunaxoides kielczewskii Michocka, Eupalopsis maseriensis (Canestrini et Fanzago), Hericia hericia Robin, Mediolata vandergeesti (Gomaa et Bolland), Michaelopus corticalis (Michael). M. corticalis, Hemisarcoptes budensis Fain et Ripka and Cheletogenes ornatus were the most frequent species in the mite fauna associated with scale insects. Corticolous mites occurred on 16 species of family Rosaceae, on 8 species of family Oleaceae, and on 4 species of family Salicaceae. Ch. ornatus was collected on coccid infested cortex, exceptionally on leaves. H. budensis, C. kielczewskii, E. maseriensis, M. mariaefrancae, $M$. vandergeesti, Neophyllobius sp. near sturmerwoodi and Neophyllobius spec. nov. were found on branches infested with the following scale insects: Pseudaulacaspis pentagona (Targioni-Tozzetti), Unaspis euonymi (Comstock), Epidiaspis leperii (Signoret), Chionaspis salicis (Linnaeus), Aulacaspis rosae (Bouché), Diaspidiotus gigas (Thiem et Gerneck), Diaspidiotus ostreaeformis (Curtis), Diaspidiotus perniciosus (Comstock), and Lepidosaphes ulmi (Linnaeus) (for more data on Coccoidea see Ripka et al., 1996). The cortex-dwelling camerobiid, cheyletid, cunaxid, eupalopsellid and stigmaeid mites usually occurred in low numbers, but the coccid infestations were severe. Phoretic hypopodes (entomophilous deuteronymphs) of $H$. budensis were collected on Chilocorus renipustulatus (Scriba) and Chilocorus bipustulatus (L.) (Coleoptera: Coccinellidae).

M. corticalis was found under the scales of dead P. pentagona, E. leperii, $U$. euonymi, Ch. salicis, Diaspidiotus marani Zahradnik, D. gigas, D. perniciosus, L. ulmi and colonies of Pseudochermes fraxini (Kaltenbach). H. hericia was collected under the peeling (loose) bark of London plane trunk. Since the paper of Ripka et al. (1997) an other tarsonemid mite was found associated with coccid. Tarsonemus bachmaieri Cooreman, 1958 was found under the scales of Carulaspis juniperi (Bouché). Oribatids were found only on bark of twigs in parks, cemetery and arboreta. They could not be found on street trees. The oribatid mites do not tolerate the aerial pollution in urban habitat. The vast majority of corticolous mite species is slow-moving, exception T. immanis. 


\section{Table 1}

Corticolous mite species collected from ornamental trees and shrubs $\left({ }^{*}=\right.$ new species for the Hungarian fauna)

\begin{tabular}{|c|c|c|c|}
\hline Mite species & Plant species & Sampling place & Sampling date \\
\hline \multicolumn{4}{|c|}{$\begin{array}{l}\text { Acari: Prostigmata } \\
\text { fam. Cheyletidae }\end{array}$} \\
\hline \multicolumn{4}{|c|}{ Cheletacarus raptor Volgin, 1961} \\
\hline & Populus $\mathrm{x}$ canescens & Óbuda & 25.08. 1998 \\
\hline & Populus simonii & Vérmező & 25.01. 1991 \\
\hline & Rhamnus catharticus & Józsefváros & 04.01. 1995 \\
\hline \multicolumn{4}{|c|}{ Cheletogenes ornatus (Canestrini et Fanzago, 1876) } \\
\hline & Celastrus orbiculatus & Gellérthegy & 09.09. 1997 \\
\hline & Crataegus laevigata & Gellérthegy & 05.02. 1991 \\
\hline & & Pestszentlörinc & 02.09. 1992 \\
\hline & Ilex aquifolium & Városliget & 04.02. 1995 \\
\hline & Jasminum beesianum & Gellérthegy & 27.01. 1995 \\
\hline & Populus $\mathrm{x}$ canescens & Óbuda & 25.08. 1998 \\
\hline & Populus simonii & Sasad & 13.09. 1991 \\
\hline & Populus tremula & Újpalota & 30.08. 1994 \\
\hline & Prunus avium & Kispest & 02.04. 1992 \\
\hline & Thuja occidentalis & Budaörs (Pest c.) & 07.03. 1995 \\
\hline \multicolumn{4}{|c|}{ Prosocheyla traubi (Baker, 1949) } \\
\hline & Populus simonii & Sasad & 13.09. 1991 \\
\hline \multicolumn{4}{|c|}{ fam. Eupalopsellidae } \\
\hline \multicolumn{4}{|c|}{ *Eupalopsis maseriensis (Canestrini et Fanzago, 1876) } \\
\hline & Crataegus laevigata & Gellérthegy & 24.01. 1995 \\
\hline & Crataegus monogyna & Gellérthegy & 26.01. 1995 \\
\hline & Malus pumila var. niedzwetzkyana & Gellérthegy & 26.01. 1995 \\
\hline \multicolumn{4}{|c|}{ fam. Stigmaeidae } \\
\hline \multicolumn{4}{|c|}{ Mediolata mariaefrancae André, 1977} \\
\hline & Euonymus europaeus & Gellérthegy & 15.06. 1997 \\
\hline & Jasminum beesianum & Gellérthegy & 27.01. 1995 \\
\hline & Rhamnus catharticus & Józsefváros & 04.01. 1995 \\
\hline & Tilia $\mathrm{x}$ euchlora & Józsefváros & 29.06. 1994 \\
\hline \multicolumn{4}{|c|}{ *Mediolata vandergeesti (Gomaa et Bolland, 1982) } \\
\hline & Crataegus monogyna & Gellérthegy & 26.01. 1995 \\
\hline & Ribes uva-crispa & Széchenyi-hegy & 04.02. 1991 \\
\hline \multicolumn{4}{|c|}{ fam. Camerobiidae } \\
\hline \multicolumn{4}{|c|}{ *Neophyllobius sp. near sturmerwoodi Bolland, 1991} \\
\hline & Juglans nigra & Köbánya & 29.03. 1995 \\
\hline \multicolumn{4}{|c|}{ "Neophyllobius sp. nov. } \\
\hline & Euonymus europaeus & Gellérthegy & 15.06. 1997 \\
\hline & Euonymus europaeus & Gellérthegy & 09.09. 1997 \\
\hline
\end{tabular}




\section{Table 1 (cont.)}

\begin{tabular}{llll}
\hline Mite species & Plant species & Sampling place & Sampling date \\
\hline fam. Cunaxidae & & & \\
${ }^{*}$ Cunaxoides kielczewskii $\begin{array}{l}\text { Michocka, 1982 } \\
\text { Picea pungens }\end{array}$ & Orosháza (Békés c.) & 07.07. 1998 \\
& Rhus typhina & Köbánya & 04.01. 1995 \\
& Taxus baccata & Orbán-hegy & 25.08. 1994
\end{tabular}

fam. Tarsonemidae

Tarsonemus bachmaieri Cooreman, 1958

$$
\text { Thuja sp. }
$$

Józsefváros

Tarsonemus nodosus Schaarschmidt, 1959

\section{Celastrus orbiculatus \\ Euonymus europaeus}

Tarsonemus waitei Banks, 1912

Euonymus europaeus

\section{Acari: Astigmata}

\section{fam. Hemisarcoptidae}

Hemisarcoptes budensis Fain et Ripka, 1998

Celastrus orbiculatus

Crataegus laevigata

Euonymus europaeus

Fraxinus angustifolia

Fraxinus pennsylvanica

Malus baccata

Phellodendron amurense

Populus $\mathrm{x}$ canescens

Populus simonii

Prunus domestica

Pyrus betulifolia

Pyrus pyraster

Rhus typhina

Sophora japonica

\section{fam. Acaridae}

*Michaelopus corticalis (Michael, 1885)

Acer platanoides Acer pseudoplatanus

Celastrus orbiculatus

Celastrus scandens

Cornus alba
Gellérthegy

Gellérthegy

Gellérthegy

Gellérthegy

Víziváros

Óbuda

Víziváros

Gellérthegy

Margitsziget

Óbuda

Óbuda

Lágymányos

Sasad

Újpalota

Gellérthegy

Józsefváros

Kőbánya

Víziváros
09.09. 1997

24.01. 1995

27.01. 1995

15.06. 1997

08.02. 1991

11.09. 1991

08.02. 1991

24.01. 1995

21.02. 1991

03.04. 1991

25.08.1998

05.02. 1991

13.09. 1991

12.02. 1991

18.01. 1995

04.01. 1995

04.01. 1995

11.02. 1991

Orosháza (Békés c.) 07.07. 1998

Csongrád (Csongrád c.) 26.05. 1998

Gellérthegy

07.08. 1998

Józsefváros

04.01. 1995

Ōrmező 28.03. 1995 
Table 1 (cont.)

\begin{tabular}{|c|c|c|c|}
\hline Mite species & Plant species & Sampling place & Sampling date \\
\hline & Cornus stolonifera & Örmező & 10.02. 1995 \\
\hline & Crataegus laevigata & Gellérthegy & 24.01. 1995 \\
\hline & Crataegus monogyna & Gellérthegy & 26.01. 1995 \\
\hline & Crataegus succulenta & Gellérthegy & 24.01. 1995 \\
\hline & Daphne mezereum & Gellérthegy & 24.01. 1995 \\
\hline & \multirow[t]{2}{*}{ Euonymus europaeus } & Gellérthegy & 27.01. 1995 \\
\hline & & Gellérthegy & 09.09. 1997 \\
\hline & \multirow[t]{2}{*}{ Forsythia suspensa } & Pasarét & 17.09. 1990 \\
\hline & & Belváros & 10.04. 1993 \\
\hline & Fraxinus excelsior & Pasarét & 17.05. 1991 \\
\hline & Ilex aquifolium & Városliget & 04.02. 1995 \\
\hline & Jasminum beesianum & Gellérthegy & 27.01. 1995 \\
\hline & Ligustrum vulgare & Tabán & 08.05. 1991 \\
\hline & Malus baccata & Gellérthegy & 24.01. 1995 \\
\hline & Malus halliana & Tabán & 05.05. 1992 \\
\hline & Malus $\mathrm{x}$ purpurea & Vérmező & 05.05. 1992 \\
\hline & Phellodendron amurense & Margitsziget & 21.02. 1991 \\
\hline & \multirow[t]{2}{*}{ Populus alba } & Budafok & 07.02. 1995 \\
\hline & & Örmező & 12.05. 1995 \\
\hline & Populus $\mathrm{x}$ canescens & Óbuda & 25.08. 1998 \\
\hline & \multirow[t]{2}{*}{ Populus simonii } & Vérmező & 25.01. 1991 \\
\hline & & Sasad & 23.09. 1991 \\
\hline & \multirow[t]{2}{*}{ Prunus cerasifera } & Tabán & 07.02. 1991 \\
\hline & & Gellérthegy & 08.05. 1991 \\
\hline & Prunus fruticosus & Zugló & 18.03. 1995 \\
\hline & Prunus spinosa & Vérmező & 07.03. 1993 \\
\hline & Pyrus betulifolia & Gellérthegy & 18.01. 1995 \\
\hline & Pyrus pashia & Gellérthegy & 18.01. 1995 \\
\hline & Pyrus pyraster & Józsefváros & 04.01 .1995 \\
\hline & Rhus typhina & Kőbánya & 04.01 .1995 \\
\hline & Syringa vulgaris & Tabán & 12.02. 1991 \\
\hline
\end{tabular}

\section{fam. Glycyphagidae}

*Hericia hericia Robin, 1868

Platanus $\mathrm{x}$ hispanica

Józsefváros

16.05. 1991

\section{Acari: Oribatida}

fam. Micreremidae

Micreremus brevipes (Michael, 1888)

Crataegus monogyna

Daphne mezereum

Malus spectabilis

Prunus spinosa

Quercus ilex
Gellérthegy

Gellérthegy

Törökvész

Vérmezõ

Lanterna (Croatia)
26.01. 1995

24.01. 1995

03.04. 1992

07.03. 1993

05.07. 1996

fam. Oribatulidae

Phauloppia conformis (Berlese, 1895)

Juglans nigra

Kőbánya

29.03. 1995 
Table 1 (cont.)

\begin{tabular}{|c|c|c|c|}
\hline Mite species & Plant species & Sampling place & Sampling date \\
\hline \multicolumn{4}{|c|}{ fam. Cymbaeremaeidae } \\
\hline \multicolumn{4}{|c|}{ Scapheremaeus reticulatus (Berlese, 1910) } \\
\hline & Ilex aquifolium & Városliget & 04.02. 1995 \\
\hline & Malus pumila var. niedzwetzkyana & Gellérthegy & 26.01. 1995 \\
\hline \multicolumn{4}{|c|}{ fam. Ceratozetidae } \\
\hline \multicolumn{4}{|c|}{ Trichoribates trimaculatus (C. L. Koch, 1836) } \\
\hline & Jasminum beesianum & Gellérthegy & 27.01. 1995 \\
\hline \multicolumn{4}{|c|}{ fam. Scheloribatidae } \\
\hline \multicolumn{4}{|c|}{ Scheloribates latipes (C. L. Koch, 1844) } \\
\hline & Jasminum beesianum & Gellérthegy & 27.01. 1995 \\
\hline
\end{tabular}

\section{Discussion}

The corticolous fauna of species Acari has not been so far investigated extensively in Hungary.

The studies of Lebrun (1976), André (1986), also Momen and Lundqvist (1996) testify that the expected mite species living in a relatively small area can appear surprisingly rich.

The bark and bark crevices are the most important overwintering sites of foliagedwelling mites. Some of them viz. tetranychid, tenuipalpid, phytoseiid, stigmaeid, tydeid, winterschmidtiid species overwinter under the shield of dead coccids (Ripka, 1998a, b, Ripka and Kaźmierski, 1998a, b). There is a closer association between some members of family Tarsonemidae and coccids. Tarsonemus nodosus, T. lobosus, T. karli, T. waitei and Dendroptus willmanni also an other Dendroptus sp. quite often were found together with scale insects (Ripka et al., 1997). Fungivorous tarsonemid mites prefer this microhabitat. They feed on microscopic fungi.

Some tydeid species gave definite preference to cortex.

The predaceous members of corticolous camerobiid, cheyletid, cunaxid, eupalopsellid, hemisarcoptid, stigmaeid and tydeid mite fauna cannot play a great role in regulating numbers of phytophagous insects and mites because of their low densities. But the knowledge on the predatory activities of these mites is sparse and mostly brief.

\section{Acknowledgements}

Cunaxoides kielczewskii (Acari: Cunaxidae) was identified by Robert L. Smiley, (Systematic Entomology Laboratory, Agricultural Research Service, US Department of Agriculture, Beltsville). Our thanks are due to Mr. R. L. Smiley for identifying this species. Special thanks are also expressed to Dr. Sándor Mahunka (Hungarian Natural History Museum, Budapest) and Dr. Wojciech Ł. Magowski (A. Mickiewicz University, Poznań) for identifying of oribatid and tarsonemid mites, respectively.

The study was supported by Ministry of Agriculture and Regional Development, Hungary. 


\section{Literature}

André, H. M. (1986): Notes on the ecology of corticolous epiphyte dwellers. 4. Actinedida (especially Tydeidae) and Gamasida (especially Phytoseiidae). Acarologia 27, 107-115.

André, H. M. (1987): Tydeidae (Acari: Tydeidae) from Belgium II. The genera Tydeus, Idiolorryia and Metalorryia. Acarologia 28, 151-159.

Balogh, J. and Mahunka, S. (1980): Mites XV. - Acari XV. Oribatida I. Fauna Hung., 139 (8), Akadémiai Kiadó, Budapest, 1-177.

Bolland, H. R. (1983): A description of Neophyllobius aesculi n. sp. and its developmental stages (Acari: Camerobiidae). Entomologische Berichten 43, 42-47.

Bolland, H. R. (1986): Review of the systematics of the family Camerobiidae (Acari, Raphignathoidea). I. The genera Camerobia, Decaphyllobius, Tillandsobius and Tycherobius. Tijdshrift voor Entomologie 129, 191-215.

Bolland, H. R. (1991): Review of the systematics of the Camerobiidae, II. The genus Neophyllobius Berlese, 1886 (Acari: Raphignathoidea). Genus 2, 59-226.

Cooreman, J. (1958): Description de Tarsonemus bachmaieri n. sp. (Tarsonemidae) et note sur Eupalopsellus ölandicus Sellnick (Eupalopsellidae). Bulletin of Institut royal des Sciences naturelles de Belgique 34, 1-8.

Doberski, J. (1986): Population dynamics of corticolous mites of the genus Daidalotarsonemus (Acari: Tarsonemidae) on elm coppice. Acarologia 28, 31-36.

Fain, A. (1982): Revision des genres Thyreophagus Rondani, 1874 et Michaelopus Fain et Johnston, 1974 (Acari, Acaridae) avec description de neuf especes nouvelles. Bull. Inst. r. Sci. nat. Belg. 54, 1-47.

Fain, A., Hurst, G. D. D., Tweddle, J. C., Lachlan, R. F., Majerus, M. E. N. and Britt, D. P. (1995): Description and observations of two new species of Hemisarcoptidae from deutonymphs phoretic on Coccinellidae (Coleoptera) in Britain. Internat. J. Acarol. 21, 99-106.

Fain, A. and Ripka, G. (1998): A new species of Hemisarcoptes Lignieres, 1893 (Acari: Hemisarcoptidae) from ornamental trees in Hungary. Internat. J. Acarol. 24, 33-39.

Gerson, U. (1973): The mites associated with armored scale insects. In: Daniel, M. and Rosicky, B. (eds): Proceedings of the 3rd International Congress of Acarology, Prague, 653-654.

Gerson, U. (1985): Other predaceous mites and spiders. In: Helle, W. and Sabelis, M. W. (eds): Spider mites their biology, natural enemies and control. Elsevier, Amsterdam, Oxford, New York, Tokyo. 205-210.

Kehl, C. and Weigmann, G. (1992): Die Hornmilbenzönosen (Acari, Oribatida) an Apfelbäumen im Stadtgebiet von Berlin als Bioindikatoren für die Luftqualität. Zool. Beitr. N. F. 34, 261-271.

Keifer, H. H. (1952): Eriophyid Studies XIX. The Bulletin Department of Agriculture State of California. 41, 65-74.

Keifer, H. H. (1975): Eriophyoidea Nalepa. In: Jeppson, L. R., Keifer, H. H. and Baker, E. W. (eds): Mites Injurious to Economic Plants. University of California Press, Berkeley, Los Angeles, London, 327-397.

Komlovszky, I. Sz. (1980): A dendrofil atkák minőségi és mennyiségi viszonyai. Kandidátusi értekezés. (Qualitative and quantitative relations of dedrophil mites. PhD thesis). Szarvas-Budapest, $114+\mathrm{xxx}$ pp. (in Hungarian).

Komlovszky, I. Sz. (1984): A fenyők (Coniferopsida) kártevő és ragadozó atka fajai. (Phytophagous and predatory mites on conifers [Coniferopsida]). Növényvédelem 20, 166-173. (in Hungarian).

Lebrun, Ph. (1976): Effets écologiques de la pollution atmoshérique sur les populations et communautés de microarthropodes corticoles (Acariens, Collemboles et Ptérygotes). Bull. Ecol. 7, 417-430.

Lucza, Z., Ripka, G. and Saly, K. R. (1996): Data to the Cheyletidae (Acari: Prostigmata) fauna of Hungary. Folia Entomologica Hungarica 57, 105-108.

Meyer, M. K. P. (Smith) and Ueckermann, E. A. (1984): The family Eupalosellidae (Acari: Prostigmata), with descriptions of new species from South Africa. Phytophylactica 16,121-142.

Momen, F. M. (1987): The mite fauna of an unsprayed apple orchard in Ireland. Angewandte Zoologie 4, $417-431$. 
Momen, F. M. (1988): New species of mites of the family Tydeidae (Acarina: Prostigmata) collected from unsprayed apple trees in Ireland. Acarologia 29, 355-360.

Momen, F. and Lundqvist, L. (1996): Taxonomy of non-Tydeus genera of mite family Tydeidae (Acari: Prostigmata) from moss, lichens and trees in southern Sweden. Acarologia 37, 281-297.

Nachev, P. D. and Trenchev, G. (1987): The acarofauna associated with some Coccidae in Bulgaria. Pochvoznanie, Agrokhimiya i Rastitelna Zashchita 22, 81-86. (in Bulgarian).

Ripka, G. (1998a): New data to the knowledge on the phytoseiid fauna in Hungary (Acari: Mesostigmata). Acta Phytopathologica et Entomologica Hungarica 33, 395-405.

Ripka, G. (1998b): New data to the knowledge on the tetranychid and tenuipalpid fauna in Hungary (Acari: Prostigmata). Acta Phytopathologica et Entomologica Hungarica 33, 425-433.

Ripka, G. and Kaźmierski, A. (1998a): New data to the knowledge on the tydeid fauna in Hungary (Acari: Prostigmata). Acta Phytopathologica et Entomologica Hungarica 33, 407-418.

Ripka, G. and Kaźmierski, A. (1998b): New data to the knowledge on the stigmaeid fauna in Hungary (Acari: Prostigmata). Acta Phytopathologica et Entomologica Hungarica 33, 419-424.

Ripka, G. and de Lillo, E. (1997): New data to the knowledge on the eriophyoid fauna in Hungary (Acari: Eriophyoidea). Folia Entomologica Hungarica 58, 147-157.

Ripka, G., Magowski, W. Ł. and Reider, K. (1997): Recent data on the knowledge of the fauna of tarsonemid mites (Acari: Heterostigmata) on ornamental trees and shrubs. Folia Entomologica Hungarica 58, 159-168.

Ripka, G., Saly, K. R. and Kozár, F. (1996): Újabb adatok a díszfa- és díszcserjefajok pajzstetü- és liszteske(Homoptera: Coccoidea, Aleyrodoidea) faunájának ismeretéhez a fővárosban és környékén. (Recent data to the coccid and aleyrodid fauna [Homoptera: Coccoidea, Aleyrodoidea] on woody ornamentals in the Budapest area.) Növényvédelem 32, 7-17. (in Hungarian with English summary)

Schmutterer, H. (1959): Schildläuse oder Coccoidea. In: Dahl, M. und Bischoff, H. (eds): Die Tierwelt Deutschlands. Gustav Fischer Verlag, Jena, 45, 260 pp.

Smiley, R. L. (1992): The predatory mite fauna Cunaxidae (Acari) of the world: with a new classification. Indira Publishing House, West Bloomfield, 356 pp.

Smiley, R. L. and Knutson, L. (1983): Aspects of taxonomic research and services relative to mites as biological control agents. In: Hoy, M. A., Cunningham, G. L. and Knutson, L. (eds): Biological Control of Pests by Mites. USDA, 148-164.

Suski, Z. W. (1972): Tarsonemid mites on apple trees in Poland. XI. Field observations on the distribution and significance of Tarsonemidae (Acarina, Heterostigmata) in apple orchards. Zesz. Probl. Post. Nauk Roln. 129, 139-157.

Vacante, V. (1989): Gli Acari degli agrumi in Italia. III.: Gli Acarididi (Hemisarcoptidae Oudemans, Acaridae Ewing and Nesbitt, Saproglyphidae Oudemans e Glycyphagidae Berlese). Boll. Zool. agr. Bachic. 2, 45-84.

Vacante, V. and Gerson, U. (1987): Three species of Eryngiopus (Acari: Stigmaeidae) from Italy, with key to species and summary of habitats. Redia 70, 385-401.

Weigmann, G. and Jung, E. (1992): Die Hornmilben (Acari, Oribatida) an Strassenbäumen in Stadtzonen unterschiedlicher Luftbelastung in Berlin. Zool. Beitr. N. F. 34, 273-287. 